\title{
Proinflammatory and proapoptotic markers in relation to mono and di-cations in plasma of autistic patients from Saudi Arabia
}

\author{
Afaf K El-Ansary ${ }^{1,2,3^{*}}$, Abir G Ben Bacha ${ }^{1,2,3}$ and Laila Y Al-Ayadhi ${ }^{2,3,4}$
}

\begin{abstract}
Objectives: Autism is a developmental disorder characterized by social and emotional deficits, language impairments and stereotyped behaviors that manifest in early postnatal life. This study aims to clarify the relationship amongst absolute and relative concentrations of $\mathrm{K}^{+}, \mathrm{Na}^{+}, \mathrm{Ca}^{2+}, \mathrm{Mg}^{2+}$ and/or proinflammatory and proapoptotic biomarkers.

Materials and methods: $\mathrm{Na}^{+}, \mathrm{K}^{+}, \mathrm{Ca}^{2+}, \mathrm{Mg}^{2+}, \mathrm{Na}^{+} / \mathrm{K}^{+}, \mathrm{Ca}^{2+} / \mathrm{Mg}^{2+}$ together with IL6, TNF $\alpha$ as proinflammatory cytokines and caspase 3 as proapoptotic biomarker were determined in plasma of 25 Saudi autistic male patients and compared to 16 age and gender matching control samples.

Results: The obtained data recorded that Saudi autistic patients have a remarkable lower plasma caspase3, IL6, $\mathrm{TNF} \alpha, \mathrm{Ca}^{2+}$ and a significantly higher $\mathrm{K}^{+}$compared to age and gender matching controls. On the other hand both $\mathrm{Mg}^{2+}$ and $\mathrm{Na}^{+}$were non-significantly altered in autistic patients. Pearson correlations revealed that plasma concentrations of the measured cytokines and caspase-3 were positively correlated with $\mathrm{Ca}^{2+}$ and $\mathrm{Ca}^{2+} / \mathrm{K}^{+}$ratio. Reciever Operating Characteristics (ROC) analysis proved that the measured parameters recorded satisfactory levels of specificity and sensitivity.

Conclusion: Alteration of the selected measured ions confirms that oxidative stress and defective mitochondrial energy production could be contributed in the pathogenesis of autism. Moreover, it highlights the relationship between the measured ions, IL6, TNF $\alpha$ and caspase3 as a set of signalling pathways that might have a role in generating this increasingly prevalent disorder. The role of ions in the possible proinflammation and proapoptic mechanisms of autistics' brains were hypothesized and explained.
\end{abstract}

Keywords: Ions, Caspase3, IL6, TNFa, Autism

\section{Introduction}

Children with Autism Spectrum Disorders (ASD) have impairments in three core domains: socialization, communication, and restricted interests and repetitive behaviors [1-4]. Researchers have reported that psychiatric comorbidity in ASD ranges from $41 \%$ to $70 \%[5,6]$.

Although the etiology of the disorder is unknown, recent studies have suggested that the susceptibility to autism is clearly attributable to genetic factors $[7,8]$. In addition, emerging evidence points to inflammatory and

\footnotetext{
* Correspondence: elansary@ksu.edu.sa

'Biochemistry Department, Science College, King Saud University, P.O box 22452, Zip code 11495, Riyadh, Saudi Arabia

Full list of author information is available at the end of the article
}

apoptotic mechanisms being responsible for certain neuropsychiatric disorders including autism. Vargas et al. [9] suggested neuroinflammatory processes are present in the autistic brain by showing that transforming growth factor (TGF) $\alpha 1$, macrophage chemoattractant protein (MCP) 1, interleukin (IL)6 and IL10 are increased in the brain of autistic subjects. A number of studies have also shown that inflammatory cytokines including tumor necrosis factor (TNF) $\alpha$, interferon (IFN) $\alpha$, IL1 $\alpha$, IL6, IL8 and IL12 are elevated in blood mononuclear cells, serum, plasma and cerebrospinal fluid (CSF) of autistic subjects [9-16].

The mechanisms of apoptosis induction are complex and not fully known, but some key events are identified

\section{C) Biomed Central}


that appear essential for the cell to enter apoptosis. The role of specific ions in the apoptotic process is slowly being revealed. Changes in intracellular $\mathrm{Ca}^{2+}$ have long been associated with apoptotic neuronal cell death. $\mathrm{Ca}^{2+}$ ionophores have been shown to induce ultrastructural changes, such as cell shrinkage, chromatin condensation, and DNA fragmentation, consistent with apoptosis [17-20]. Increased $\mathrm{Ca}^{2+}$ has been linked to processes occurring during apoptosis including caspase activation.

One key event in apoptosis is loss of intracellular potassium ions $\left(\mathrm{K}^{+}\right)$. Depletion of $\mathrm{K}^{+}$is necessary for cells to shrink, activate caspases and degrade DNA [21-23], events that in turn lead to further characteristic apoptotic changes such as membrane blebbing and formation of apoptotic bodies. Apoptosis due to forced loss of intracellular $\mathrm{K}^{+}$can be induced by ionophores or $\mathrm{K}^{+}$channel activators [24-26]. In addition, $\mathrm{Yu}$ et al. $[25,27]$ have also shown that the outward $\mathrm{K}^{+}$current that ensues from $\mathrm{N}$-methyl-D-aspartate receptor activation has also been shown to induce apoptotic changes in cultured hippocampal neurons.

Just as with increased $\mathrm{Ca}^{2+}$ and $\mathrm{K}^{+}$efflux, the importance of sodium $\left(\mathrm{Na}^{+}\right)$entry in inducing neuronal injury and death in response to pathophysiologic conditions, such as hypoxia, has been well established [28-34]. Moreover, Banasiak et al. [35] proved that blocking $\mathrm{Na}^{+}$entry in hypoxia-exposed neurons reduced the proportion of DNA fragmentation and reduced apoptotic cell.

Magnesium $\left(\mathrm{Mg}^{2+}\right)$ has a profound effect on neural excitability; the most characteristic signs and symptoms of $\mathrm{Mg}^{2+}$ deficiency are produced by neural and neuromuscular hyperexcitability [36]. Iotti and Malucelli [37] clarify the functional relationship between energy metabolism and free $\left[\mathrm{Mg}^{2+}\right]$, providing evidence that brain cells cytosolic $\left[\mathrm{Mg}^{2+}\right]$ is regulated to equilibrate any changes in rapidly available free energy. Moreover, it has also been shown that the measurement of brain $\mathrm{Mg}^{2+}$ can help in the differential diagnosis of neurodegenerative diseases sharing common clinical features.

The immune system has been postulated to play an important role in the etiology of autism. Investigators have proposed infectious, autoimmune, and cytokine-related etiologies.

These information initiate our interest to measure concentrations of $\mathrm{Na}^{+}, \mathrm{K}^{+}, \mathrm{Ca}^{2+}, \mathrm{Mg}^{2+}$ together with caspase3 as a proapoptotic marker, IL6 and TNF $\alpha$ as proinflammation markers in the plasma of autistic patients from Saudi Arabia in an attempt to understand the role and relationship of these biochemical parameters in the etiology of autism and its commonly related psychiatric conditions.

\section{Material and methods}

\section{Subjects and methods}

The study protocol followed the ethical guidelines of the most recent Declaration of Helsinki (Edinburgh, 2000). All subjects enrolled in the study (25 autistic male patients and 16 age and gender matched controls) had written informed consent provided by their parents and assented to participate if developmentally able. They were enrolled through the ART Center (Autism Research \& Treatment Center) clinic (Riyadh, Saudi Arabia). The ART Center clinic sample population consisted of children diagnosed on the ASD. The diagnosis of ASD was confirmed in all subjects using the Autism Diagnostic Interview-Revised (ADI-R) and the Autism Diagnostic Observation Schedule (ADOS) and 3DI (Developmental, dimensional diagnostic interview). The ages of all autistic children who participated were between the ages of 4 and 12 years old. All were simplex cases. All are negative for fragile $\times$ gene study. The control group recruited from Well baby Clinic at King Khaled University hospital with mean age 4-11 year old. Subjects were excluded from the investigation if they had organic aciduria, dysmorphic features, or diagnosis of Fragile $x$ or other serious neurological (e.g., seizures), psychiatric (e.g., bipolar disorder) or known medical conditions. All participants were screened via parental interview for current and past physical illness. Children with known endocrine, cardiovascular, pulmonary, liver, kidney or other medical disease were excluded from the study. None of the recruited autistic patients were on special diets or alternative treatments.

\section{Ethics approval and consent}

A written consent was obtained from the parents of each individual case, according to the guidelines of the ethical committee of King Khalid Hospital, King Saud University.

\section{Blood samples}

After overnight fast, $10 \mathrm{ml}$ blood samples were collected from both groups in test tubes containing sodium heparin as anticoagulant. Tubes were centrifuged at 3500 $\mathrm{rpm}$ at room temperature for 15 minutes, plasma was obtained and deep freezed $\left(\right.$ at $\left.-80^{\circ} \mathrm{C}\right)$ until analysis time.

\section{Measurement of calcium}

The UDI (United Diagnostics Industry, Saudi Arabia) $\mathrm{Ca}^{2}$ + procedure is based on the reaction of Ocresolphthalein complexone (O-CPC) with $\mathrm{Ca}^{2+}$ to form a chromogenic complex that absorbs light which is measured photometrically at $575 \mathrm{~nm} . \mathrm{Mg}^{2+}$ interference is prevented by sequestration with 8 -hydroxyquinoline. 2-Ethylaminoethanol is used to establish the reaction $\mathrm{pH}$ at 12 . Dimethyl sulfoxide is used to lower the dielectric constant of the reaction mixture and to repress the ionization of cresolphthalein complexone [38].

\section{Measurement of potassium}

$\mathrm{K}^{+}$reacts with sodium tetra phenyl boron in a protein free alkaline medium to produce a colloidal suspension 
[39]. The turbidity which is proportional to the $\mathrm{K}^{+}$concentration in the range of $2-7 \mathrm{mmol} / \mathrm{L}$ was measured against blank. The concentration was calculated using a typically treated standard solution of $\mathrm{K}^{+}$chloride in Bovine albumin equivalent to $4 \mathrm{~mol} / \mathrm{L}$.

\section{Measurement of sodium}

Plasma $\mathrm{Na}^{+}$was measured according to the method of Tietz [40] using a diagnostic kit, a product of UDI in which $\mathrm{Na}^{+}$was determined via $\mathrm{Na}+$ dependent $\beta$-galactosidase activity using $\mathrm{O}$-nitrophenyl- $\beta$, D-galactopyranoside.

\section{Measurement of magnesium}

The UDI method stems from the original work of Lindstrom and Diehl [41] using calmagite, 1-(1-hydroxy-4methyl-2- phenylazo)-2-naphthol-4-sulfonic acid, as the complexometric reagent. $\mathrm{Ca}^{2+}$ is masked by sequestration with strontium ethylene-bis-(oxyethylenenitrilo)-tetra acetate (EGTA Sr) [42]. A surfactant system has been utilized to overcome protein interference. $\mathrm{Mg}^{2+}$ form a colored complex with calmagite in alkaline medium to produce a red complex that absorbs light which is measured spectrophotometrically at $530 \mathrm{~nm}$. The absorbance of the red complex is directly proportional to the concentration of $\mathrm{Mg}^{2+}$ in the sample.

\section{Statistical analysis}

A SPSS (Statistical Package for the Social Sciences) computer program was used. Results were expressed as mean \pm S.D. and all statistical comparisons were made by means of independent $t$-test with $\mathrm{P} \leq 0.05$ was considered significant. ROC analysis was performed. Area under the curve, cutoff values together with degree of specificity and sensitivity were calculated.

\section{Results}

Table 1 and Figure 1 demonstrate concentrations of the measured parameters in plasma of autistic patients compared to control. Concentrations of caspase3, IL6 and TNF $\alpha$ were significantly lower in children with autism compared to control. In contrast, $\mathrm{K}^{+}$was significantly raised in plasma samples from children with autism compared to age and gender matching controls recording 2.3 fold higher values. In addition, $\mathrm{Ca}^{2+}, \mathrm{Ca}^{2+} / \mathrm{Mg}^{2+}$ and $\mathrm{Na}^{+} /$ $\mathrm{K}^{+}$ratio were significantly lower in autistic compared to control with the latter showing almost 3 fold lower values. Figure 2 shows the percentage changes of the measured parameters in autistics relative to control subjects. It could be easily seen that caspase3, IL6 and TNF $\alpha$ recorded more or less the average \% decrease with values of $-27.5,-20.2$ and -29.8. Among the measured elements $\mathrm{K}^{+}$recorded the most remarkable percentage increase recording value of $130 \%$ higher concentration in autistic compared to control with concomitant decrease in $\mathrm{Na}^{+} / \mathrm{K}^{+}$ratio of $69.9 \%$
Table 1 Caspase3, IL6, TNF $\alpha, \mathrm{Ca}^{2+}, \mathrm{Mg}^{2+}, \mathrm{Na}^{+}$and $\mathrm{K}^{+}$ concentrations and $\mathrm{Ca}^{2+} / \mathrm{Mg}^{2+}$ and $\mathrm{Na}^{+} / \mathrm{K}^{+}$ratios in plasma of autistic patients $(\mathrm{N}=25)$ compared to age and gender matching controls $(\mathrm{N}=16)$

\begin{tabular}{|c|c|c|c|c|c|}
\hline Parameters & Groups & Min. & Max. & Mean \pm S.D. & $P$ value \\
\hline \multirow[t]{2}{*}{ Caspase3 (ng/ml) } & Control & 135.54 & 189.47 & $170.17 \pm 13.05$ & $>0.001$ \\
\hline & Autistic & 81.94 & 158.28 & $123.40 \pm 23.37$ & \\
\hline \multirow{2}{*}{$\begin{array}{c}\mathrm{IL6} \\
(\mathrm{pg} / \mathrm{ml})\end{array}$} & Control & 303.18 & 394.41 & $343.34 \pm 28.16$ & \\
\hline & Autistic & 225.42 & 347.41 & $273.95 \pm 30.82$ & \\
\hline \multirow{2}{*}{$\begin{array}{l}\text { TNF } \alpha \\
(p g / m l)\end{array}$} & Control & 306.53 & 395.66 & $360.85 \pm 29.05$ & \\
\hline & Autistic & 129.44 & 381.28 & $253.16 \pm 64.07$ & \\
\hline \multirow{2}{*}{$\begin{array}{c}\mathrm{Ca}^{2+} \\
(\mathrm{mmol} / \mathrm{L})\end{array}$} & Control & 9.49 & 14.77 & $12.29 \pm 1.53$ & \\
\hline & Autistic & 3.17 & 6.85 & $4.42 \pm 0.87$ & \\
\hline \multirow{2}{*}{$\begin{array}{c}\mathrm{Mg}^{2+} \\
(\mathrm{mmol} / \mathrm{L})\end{array}$} & Control & 1.42 & 2.47 & $1.86 \pm 0.35$ & 0.411 \\
\hline & Autistic & 1.00 & 2.76 & $1.97 \pm 0.43$ & \\
\hline \multirow{2}{*}{$\begin{array}{c}\mathrm{Na}^{+} \\
(\mathrm{mmol} / \mathrm{L})\end{array}$} & Control & 76.20 & 139.92 & $120.92 \pm 21.94$ & 0.036 \\
\hline & Autistic & 65.18 & 123.69 & $105.06 \pm 17.43$ & \\
\hline \multirow{2}{*}{$\begin{array}{c}\mathrm{K}^{+} \\
(\mathrm{mmol} / \mathrm{L})\end{array}$} & Control & 1.20 & 7.90 & $4.76 \pm 2.04$ & $>0.001$ \\
\hline & Autistic & 3.60 & 22.30 & $10.95 \pm 5.26$ & \\
\hline \multirow[t]{2}{*}{$\mathrm{Ca}^{2+} / \mathrm{Mg}^{2+}$} & Control & 5.01 & 8.41 & $6.74 \pm 0.99$ & \\
\hline & Autistic & 1.40 & 6.82 & $2.44 \pm 1.15$ & \\
\hline \multirow[t]{2}{*}{$\mathrm{Na}^{+} / \mathrm{K}^{+}$} & Control & 10.45 & 109.14 & $34.55 \pm 26.01$ & 0.004 \\
\hline & $\overline{\text { Autistic }}$ & 4.15 & 19.57 & $10.41 \pm 4.73$ & \\
\hline
\end{tabular}

decrease. $\mathrm{Ca}^{2+} / \mathrm{Mg}^{2+}$ ratio recorded $63.8 \%$ lower values in control. Absolute values of $\mathrm{Na}^{+}$and $\mathrm{Mg}^{2+}$ recorded the lowest percentage changes recording $13.1 \%$ and 5.9\% increase, respectively. Table 2 and Figure 3 show the significantly positive and negative correlated parameters. Out of the 27 correlations recorded in table 3 , the most significantly correlated parameters were selected to be presented in Figure 3. Table 3 together with Figure 4 show ROC analysis of the measured parameters. It could be easily noticed that most of the measured parameters recorded satisfactory values of sensitivity and specificity with the exception of $\mathrm{Mg}^{2+}$ and $\mathrm{Na}^{+}$which show low specificity values.

\section{Discussion}

Protection of the brain from injury during the fetal, neonatal and postnatal periods is of major importance owing to the significant number of infants who now survive early brain injury but develop neurodevelopmental and motor disabilities.

Table 1 and Figures 1 and 2 show the unexpected lower concentrations of caspase3, TNFa and IL6. This could be interpreted on the basis that the etiology of the fetal brain damage inflammation will involve many 

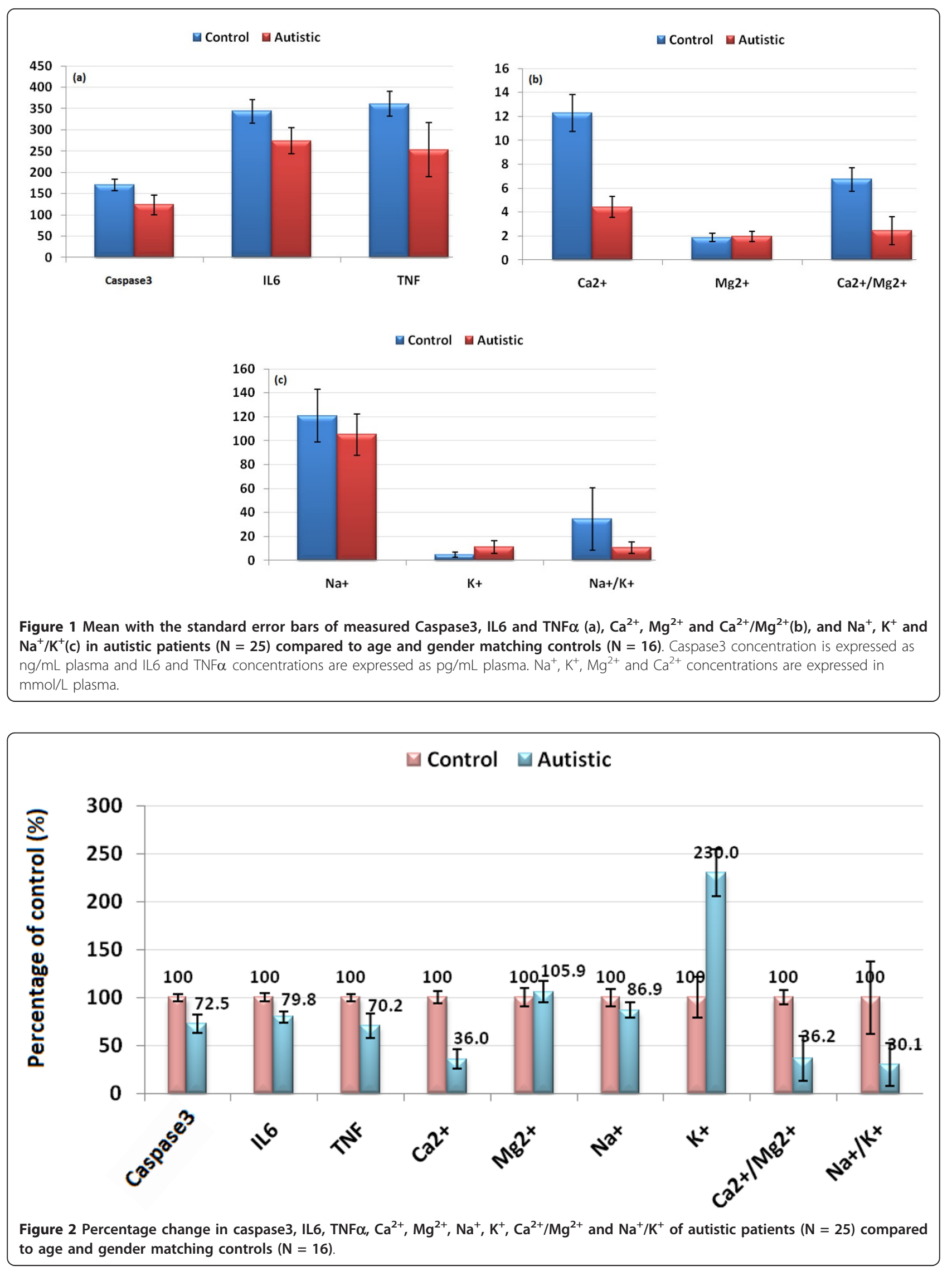
Table 2 Pearson correlation test between the measured parameters

\begin{tabular}{|c|c|c|c|}
\hline Parameters & R (Person Correlation) & & Sig. \\
\hline Caspase3 IL6 & 0.627 & + & $>0.01$ \\
\hline Caspase3 $\sim$ TNF $\alpha$ & 0.598 & + & \\
\hline Caspase $3 \sim \mathrm{Ca}^{2+}$ & 0.731 & + & \\
\hline Caspase $3 \sim \mathrm{Na}^{+}$ & 0.486 & + & \\
\hline Caspase3 $\sim \mathrm{K}+$ & -0.412 & - & \\
\hline Caspase3 $\sim \mathrm{Ca}^{2+} / \mathrm{Mg}^{2+}$ & 0.666 & + & \\
\hline Caspase $3 \sim \mathrm{Na}^{+} / \mathrm{K}^{+}$ & 0.459 & + & \\
\hline IL6 $\sim$ TNF $\alpha$ & 0.469 & + & \\
\hline $\mathrm{IL} 6 \sim \mathrm{Ca}^{2+}$ & 0.680 & + & \\
\hline IL6 $\sim \mathrm{Na}^{+}$ & 0.505 & + & \\
\hline $\mathrm{IL6} \sim \mathrm{K}^{+}$ & -0.423 & - & \\
\hline $\mathrm{IL} 6 \sim \mathrm{Ca}^{2+} / \mathrm{Mg}^{2+}$ & 0.691 & + & \\
\hline $\mathrm{IL} 6 \sim \mathrm{Na}^{+} / \mathrm{K}^{+}$ & 0.551 & + & \\
\hline $\mathrm{TNF} \alpha \sim \mathrm{Ca}^{2+}$ & 0.633 & + & \\
\hline $\mathrm{TNF} \alpha \sim \mathrm{Ca}^{2+} / \mathrm{Mg}^{2+}$ & 0.521 & + & \\
\hline $\mathrm{Ca}^{2+} \sim \mathrm{K}^{+}$ & -0.582 & - & \\
\hline $\mathrm{Ca}^{2+} \sim \mathrm{Ca}^{2+} / \mathrm{Mg}^{2}+$ & 0.912 & + & \\
\hline $\mathrm{Ca}^{2+} \sim \mathrm{Na}^{+} / \mathrm{K}^{+}$ & 0.503 & + & \\
\hline $\mathrm{Mg}^{2+} \sim \mathrm{Na}^{+}$ & -0.537 & - & \\
\hline $\mathrm{Mg}^{2+} \sim \mathrm{Ca}^{2+} / \mathrm{Mg}^{2+}$ & -0.476 & - & \\
\hline $\mathrm{Na}^{+} \sim \mathrm{Ca}^{2+} / \mathrm{Mg}^{2+}$ & 0.552 & + & \\
\hline $\mathrm{Na}^{+} \sim \mathrm{Na}^{+} / \mathrm{K}^{+}$ & 0.526 & + & \\
\hline $\mathrm{Ca}^{2+} / \mathrm{Mg}^{2+} \sim \mathrm{Na}^{+} / \mathrm{K}^{+}$ & 0.592 & + & \\
\hline $\mathrm{K}^{+} \sim \mathrm{Ca}^{2+} / \mathrm{Mg}^{2+}$ & -0.604 & - & \\
\hline $\mathrm{K}^{+} \sim \mathrm{Na}^{+} / \mathrm{K}^{+}$ & -0.650 & - & \\
\hline $\mathrm{Na}^{+} \sim \mathrm{K}^{+}$ & -0.363 & - & 0.049 \\
\hline
\end{tabular}

Correlation is significant at the 0.01 level (2-tailed).

${ }^{+}$Positive Correlation

Negative Correlation

factors and is likely to include an increase in circulating cytokine concentrations. Rees et al. [43] have shown, for example that TNF $\alpha$ [44] and IL6 concentrations [45] increase within the early 6 hours of lipopolysaccharide (LPS) exposure. It has been proposed that circulating cytokines might act on cerebralendothelial cells or periventricular cells to upregulate prostaglandin synthesis, resulting in increased permeability of the blood-brain barrier [46]; thus the administration of LPS to fetal sheep results in the extravasation of plasma proteins and macrophages into the brain [46].

TNF $\alpha$ and IL6 are cytokines involved in cell-mediated immune response and their production has been shown to be associated with tissue inflammation and necrosis [47]. Based on these information, the recorded lower plasma concentrations of these two cytokines does not oppose with the neuroinflammatory model recently proved for autism [48]. This could help us to suggest that localized inflammation of the central nervous system may contribute to the pathogenesis of autism and that elevation of plasma cytokines could be an early event followed by infiltration of macrophages, cytokines and proapotic factors across the BBB to the brain. The lower recorded concentration of caspase 3 in autistics compared to control subjects could be easily related to the decrease in TNF $\alpha$. This could be supported through considering the previous report of Mundle et al. [49] which demonstrated a link between TNF $\alpha$ and the major effectors of its apoptotic signal, i.e. Caspase 1 and 3 . They identify the downstream effectors of TNF $\alpha$ apoptotic signalling and show a positive correlation of TNF $\alpha$ with Caspase3.

A major endogenous antioxidant in mammalian cells is the enzyme superoxide dismutase (SOD), which catalyzes the dismutation of the superoxide anion $\left(\mathrm{O}_{2}{ }^{-}\right)$into hydrogen peroxide $\left(\mathrm{H}_{2} \mathrm{O}_{2}\right)$ and molecular oxygen $\left(\mathrm{O}_{2}\right)$. Dimayuga et al. [50] show that overexpression of SOD1 in microglial cells leads to significant decreases in superoxide concentrations, with corresponding increases in $\mathrm{H}_{2} \mathrm{O}_{2}$ concentrations. They proved that the release of the proinflammatory cytokines TNF $\alpha$ and IL6 is significantly attenuated by overexpression of SOD1. With special consideration of the effect of population, the recorded lower concentrations of TNF $\alpha$ and IL6 in autistic patients as subjects of the present study compared to controls could be related to the overexpression of SOD previously reported as metabolic biomarker in Saudi autistic patients [51].

Table 1 and Figure 2 demonstrate that autistic patients from Saudi Arabia recorded lower concentrations of plasma $\mathrm{Ca}^{2+}$. This could find a support through considering the work of Shearer et al. [52] in which they observed lower $\mathrm{Ca}^{2+}$ concentrations in the hair of autistic population and that of Krey and Dolmetsch [53] in which they proved that some forms of autism are caused by failures in activity-dependent regulation of neural development due to mutations of several voltage-gated and ligandgated ion channels that regulate neuronal excitability and $\mathrm{Ca}^{2+}$ signalling. On the other hand, the recorded lower concentration of $\mathrm{Ca}^{2+}$ is not in accordance with the recent work of Laura et al. (2011) [54] which reported higher $\mathrm{Ca}^{2+}$ concentrations in plasma of Italian autistic patients compared to age and gender matching controls. The reduced plasma $\mathrm{Ca}^{2+}$ concentrations of the present study could be associated with high intracellular brain $\mathrm{Ca}^{2+}$ in autistics compared to control subjects. This suggestion could be supported with the recent evidence from post-mortem studies of autistic brains which points toward abnormalities in mitochondrial function as possible downstream consequences of dysreactive immunity and altered $\mathrm{Ca}^{2+}$ signalling [55]. Low plasma $\mathrm{Ca}^{2+}$ and the speculated high brain $\mathrm{Ca}^{2+}$ concentration could be easily correlated to the oxidative stress previously 


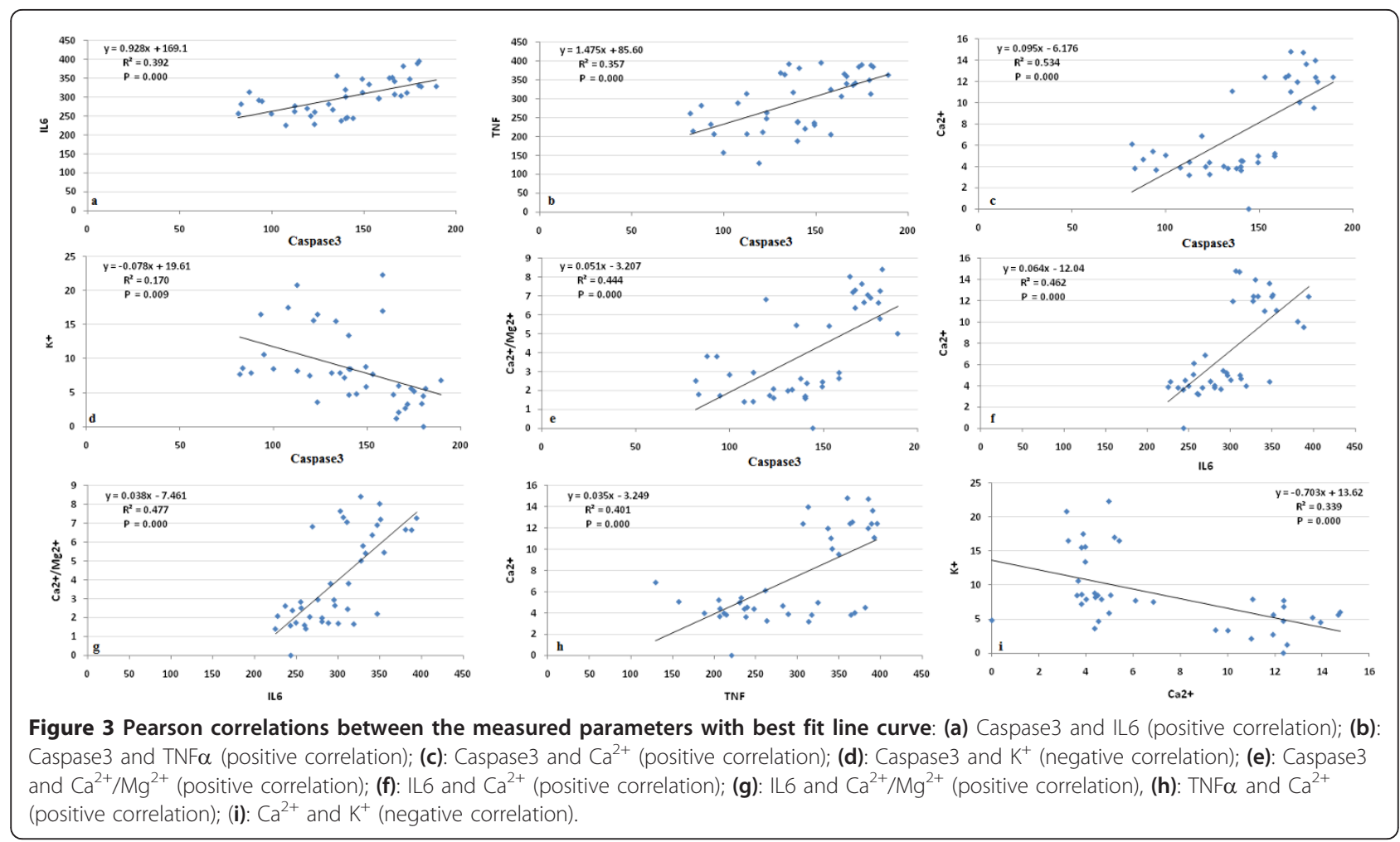

recorded in Saudi autistic patients [56] as elevated brain $\mathrm{Ca}^{2+}$ is recently related to ROS generation. Mitochondrial aspartate/glutamate carrier (AGC1), isoform predominantly expressed in the brain, heart and skeletal muscle, is known to play a pivotal role in energy metabolism and is regulated by neurone intracellular $\mathrm{Ca}^{2+}[57,58]$. This carrier was found to be approximately three-fold higher in brain homogenates from each of six autistic patients compared to their matched controls. This could support the lower plasma $\mathrm{Ca}^{2+}$ concentrations recorded in the present study. Moreover, direct fluorimetric measurements of $\mathrm{Ca}^{2+}$ concentrations in the post-mortem mitochondrial supernatant confirmed significantly higher $\mathrm{Ca}^{2+}$ concentrations in brain of autistics [55].
This suggested increased influx of blood-to-brain $\mathrm{Ca}^{2+}$ could be easily related to the loss of amyloid beta $(A \beta)$ equilibrium between the brain and blood which may lead to failure of drawing out $A \beta$ from the brain across the blood brain barrier (BBB) as a mechanism for $A \beta$ accumulation in Saudi autistics [Al-Ayahdi L, Ben Bacha A, Kotb M, El-Ansary A: A novel study on amyloid $\beta$ peptide 40, 42 and $40 / 42$ ratio in Saudi autistics, Submitted]. Vitamin E which is known to attenuate A $\beta$-induced apoptosis despite $\mathrm{Ca}^{2+}$ accumulation in brain cells is significantly lower in Saudi autistic patients [51]. This could support the suggested mechanism relating $A \beta$ and $\mathrm{Ca}^{2+}$ - induced apoptosis in brain cells of Saudi autistics.

Table $3 \mathrm{ROC}$ analysis of $\mathrm{Ca}^{2+} / \mathrm{Mg}^{2+}$ and $\mathrm{Na}^{+} / \mathrm{K}^{+}$ratios and Caspase3, IL6, TNF $\alpha, \mathrm{Ca}^{2+}, \mathrm{Mg}^{2+}, \mathrm{Na}^{+}$and $\mathrm{K}^{+}$in autistic groups $(\mathbf{N}=\mathbf{2 5})$

\begin{tabular}{|c|c|c|c|c|}
\hline Parameter & Area under the curve & Best Cutoff value & Sensitivity $\%$ & Specificity \% \\
\hline Caspase3 & 0.968 & 161.17 & $100.0 \%$ & $86.7 \%$ \\
\hline IL6 & 0.952 & 301.95 & $84.0 \%$ & $100.0 \%$ \\
\hline TNF $\alpha$ & 0.915 & 297.67 & $76.0 \%$ & $100.0 \%$ \\
\hline $\mathrm{Ca}^{2+}$ & 1.000 & 8.17 & $100.0 \%$ & $100.0 \%$ \\
\hline $\mathrm{Mg}^{2+}$ & 0.592 & 1.76 & $97.2 \%$ & $53.3 \%$ \\
\hline $\mathrm{Na}^{+}$ & 0.786 & 124.50 & $100.0 \%$ & $71.4 \%$ \\
\hline$\overline{\mathrm{K}^{+}}$ & 0.900 & 7.00 & $84.0 \%$ & $85.7 \%$ \\
\hline $\mathrm{Ca}^{2+} / \mathrm{Mg}^{2+}$ & 0.981 & 4.41 & $95.8 \%$ & $100.0 \%$ \\
\hline $\mathrm{Na}^{+} / \mathrm{K}^{+}$ & 0.888 & 17.14 & $93.8 \%$ & $78.6 \%$ \\
\hline
\end{tabular}




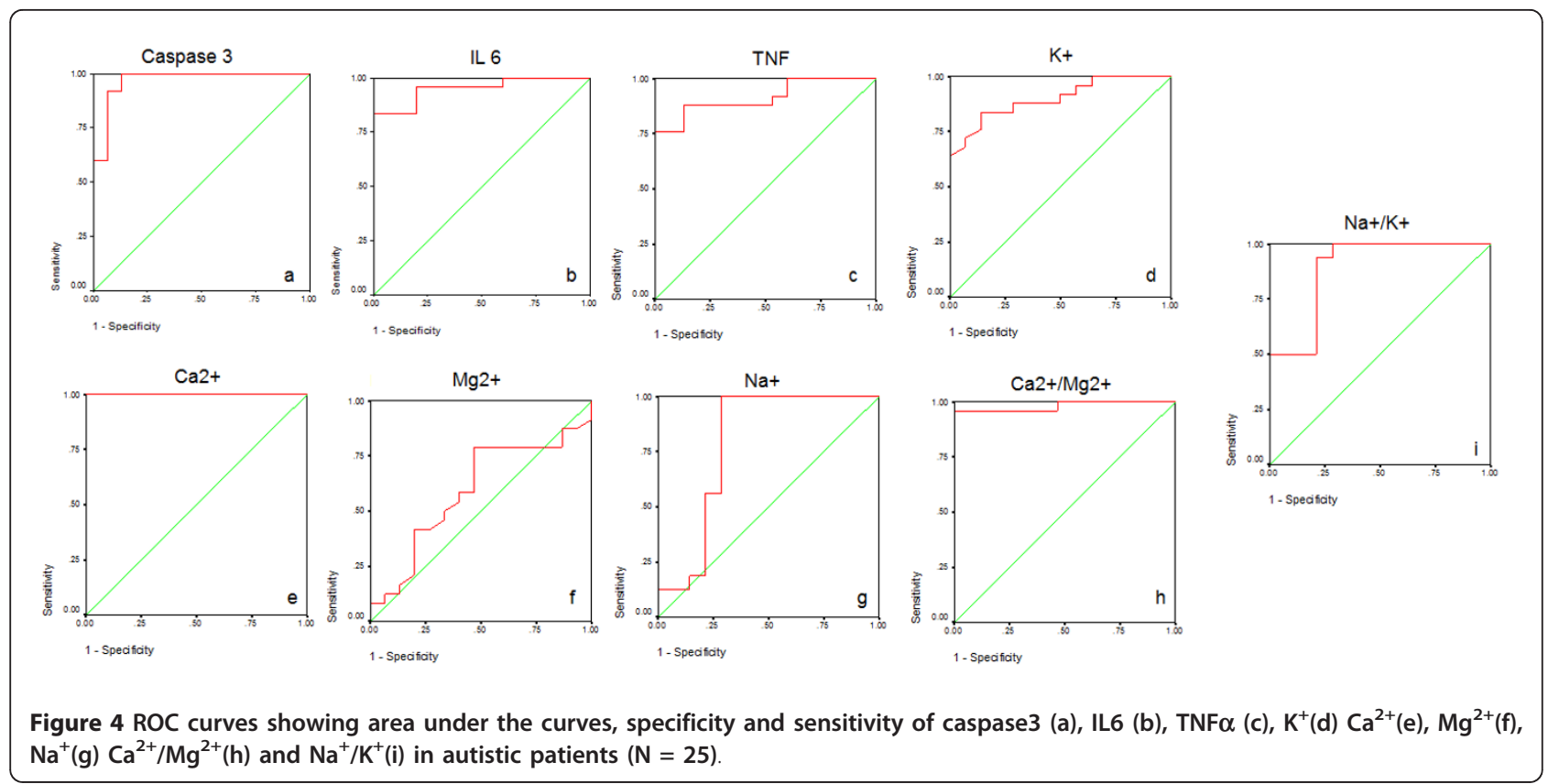

Table 1 and Figure 1 demonstrate $\mathrm{K}^{+}$concentrations in plasma of autistic and control subjects. It could be easily noticed that autistic patients recorded raised concentrations of $\mathrm{K}^{+}$compared to controls. This could be attributed to the altered $\mathrm{Na}^{+} / \mathrm{K}^{+}$ATPase activity previously reported by El-Ansary et al. [56], which may represent an important neurotoxic mechanism for neurons.

The recorded higher plasma concentrations of $\mathrm{K}^{+}$ which reflect the remarkable higher rate of $\mathrm{k}^{+}$efflux from brain to blood in autistic patients could be easily related to the significant lower $\mathrm{Ca}^{2+}$, the unchanged $\mathrm{Na}^{+}$, lower $\mathrm{Ca}^{2+} / \mathrm{Na}^{+}$ratios and to the speculated higher brain caspase3 activity. Xiao et al. [59] showed previously that activation of the N-methyl-D-aspartic acid (NMDA) subtype of glutamate receptors in a low $\mathrm{Ca}^{2}$ and $\mathrm{Na}^{+}$condition induced apoptotic neuronal death, and that the $\mathrm{K}^{+}$ efflux via NMDA receptor channels was likely a key event in NMDA-induced apoptosis. This postulation could be supported by Pigozzi et al. [60] who proved that entry of $\mathrm{Ca}^{2+}$ into neuron cells can accelerate apoptosis by accelerating the expression of growth arrest and DNA Damage inducible gene 153 (GADD153) and by inducing a prolonged efflux of $\mathrm{K}^{+}$out of the cell. This is in good agreement with the elevated $\mathrm{K}^{+}$and the reduced $\mathrm{Ca}^{2+}$ concentrations in plasma of autistic patients compared to controls as a report of the present study. Moreover, the significantly impaired $\mathrm{Ca}^{2+}$ and $\mathrm{K}^{+}$concentrations in plasma of autistic patients could be easily related to the postulated increase of brain cytokines (TNF $\alpha$ and IL6) after infiltration from plasma to brain. Experimental evidence demonstrates that ion channels are targeted by cytokines, which can specifically modulate their function [61] and TNF $\alpha$ was associated with the remarkable $\mathrm{Ca}^{2+}$ influx from blood to brain [62]. These suggested mechanisms of the alteration of the studied parameters could be supported through the obtained Pearson correlations presented in table 3 and Figure 3.

ROC analysis presented in Figure 4, support the previous discussion and suggestions which based on the obtained data. Most of the measured parameters recorded AUC near 1 and satisfactory levels of specificity and sensitivity and hence they could be used as biochemical markers for the early diagnosis of autism in Saudi population.

\section{Acknowledgements}

The authors extend their appreciation to the Deanship of Scientific Research at King Saud University for funding the work through the research group project No (RGP-VPP-005).

\section{Author details}

${ }^{1}$ Biochemistry Department, Science College, King Saud University, P.O box 22452, Zip code 11495, Riyadh, Saudi Arabia. ${ }^{2}$ Autism Research and Treatment Center, Riyadh, Saudi Arabia. ${ }^{3}$ Shaik AL-Amodi Autism Research Chair, King Saud University, Riyadh, Saudi Arabia. ${ }^{4}$ Department of Physiology, Faculty of Medicine, King Saud University, Riyadh, Saudi Arabia.

\section{Authors' contributions}

AE designed the study and drafted the manuscript. ABB helped to draft the manuscript and performed the statistical analysis. LA provided samples and participated in the design of the study. All authors have read and approved the final manuscript.

\section{Competing interests}

The authors declare that they have no competing interests.

Received: 28 May 2011 Accepted: 15 October 2011

Published: 15 October 2011 


\section{References}

1. Matson JL, Gonzalez M, Wilkins JP: Validity study of the Autism Spectrum Disorders-Diagnostic for Children (ASD-DC). Research in Autism Spectrum Disorders 2009, 3:196-206.

2. Matson JL, LoVullo SV: Trends and topics in autism spectrum disorders research. Research in Autism Spectrum Disorders 2009, 3:252-257.

3. Matson $J$, Neal D: Diagnosing high incidence autism spectrum disorders in adults. Research in Autism Spectrum Disorders 2009, 3:581-589.

4. Njardvik V, Matson $\mathrm{L}$, Cherry KE: A comparison of social skills in adults with autistic disorders, pervasive developmental disorders not otherwise specified, and metnal retardation. Journal of Autism and Developmental Disorders 1999, 29:287-295.

5. Morgan CN, Roy M, Chance P: Psychiatric comorbidity and medication use in autism: A community survey. Psychiatric Bulletin 2003, 27(Suppl 10):378-381.

6. Simonoff E, Pickles A, Charman T, Chandlew S, Loucas T, Biard G: Psychiatric disorders in children with autism spectrum disorders: Prevalence, comorbidity, and associated factors in a population-derived sample. Journal of the American Academy of Child and Adolescent Psychiatry 2008, 47:921-929.

7. Abrahams BS, Geschwind DH: Advances in autism genetics: on the threshold of a new neurobiology. Nat Rev Genet 2008, 9:341-355.

8. Folstein SE, Rosen-Sheidley B: Genetics of autism: complex aetiology for a heterogeneous disorder. Nat Rev Genet 2001, 2:943-955.

9. Vargas DL, Nascimbene C, Krishnan C, Zimmerman AW, Pardo CA: Neuroglial activation and neuroinflammation in the brain of patients with autism. Ann Neurol 2005, 57:67-81.

10. Jyonouchi H, Sun S, Le H: Proinflammatory and regulatory cytokine production associated with innate and adaptive immune responses in children with autism spectrum disorders and developmental regression. J Neuroimmunol 2001, 120:170-179.

11. Jyonouchi $\mathrm{H}$, Sun $\mathrm{S}$, Itokazu $\mathrm{N}$ : Innate immunity associated with inflammatory responses and cytokine production against common dietary proteins in patients with autism spectrum disorder. Neuropsychobiology 2002, 46:76-84.

12. Singh VK: Plasma increase of interleukin-12 and interferon-gamma: Pathological significance in autism. Journal of Neuroimmunology 1996 66:143-145.

13. Croonenberghs J, Bosmans E, Deboutte D, Kenis G, Maes M: Activation of the inflammatory response system in autism. Neuropsychobiology 2002, 45(suppl 1):1-6.

14. Molloy CA, Morrow AL, Meinzen-Derr J, Schleifer K, Dienger K, ManningCourtney $\mathrm{P}$, Altaye M, Wills-Karp M: Elevated cytokine levels in children with autism spectrum disorder. Journal of Neuroimmunology 2006, 172:198-205

15. Ashwood P, Wakefield AJ: Immune activation of peripheral blood and mucosal CD3a lymphocyte cytokine profiles in children with autism and gastrointestinal symptoms. J Neuroimmunol 2006, 173:126-134.

16. Chez MG, Burton Q, Dowling T, Chang M, Khanna P, Kramer C: Memantine as adjunctive therapy in children diagnosed with autistic spectrum disorders: an observation of initial clinical response and maintenance tolerability. J Child Neurol 2007, 22:574-579.

17. Joseph R, Li W, Han E: Neuronal death, cytoplasmic calcium and internucleosomal DNA fragmentation: evidence for DNA fragments being released from cells. Mol Brain Res 1993, 17:70-76.

18. Zhong LT, Sarafian T, Kane DJ, Charles AC, Mah SP, Edwards RH, Bredesen DE: bcl-2 inhibits death of central neural cells induced by multiple agents. Proc Natl Acad Sci USA 1993, 90:4533-4537.

19. Takei $\mathrm{N}$, Endo $\mathrm{Y}$ : $\mathrm{Ca}^{+}{ }^{+}$ionophore-induced apoptosis on cultured embryonic rat cortical neurons. Brain Res 1994, 652:65-70.

20. Hatanaka Y, Suzuki K, Kawasaki Y, Endo Y, Taniguchi N, Takei N: A role of peroxides in $\mathrm{Ca}^{2+}$ ionophore-induced apoptosis in cultured rat cortical neurons. Biochem Biophys Res Comm 1996, 227:513-518.

21. Hughes FM Jr, Bortner CD, Purdy GD, Cidlowski JA: Intracellular $\mathrm{K}^{+}$ suppresses the activation of apoptosis in lymphocytes. Journal of Biological Chemistry 1997, 272:30567-30576.

22. Hughes FM Jr, Cidlowski JA: Potassium is a critical regulator of apoptotic enzymes in vitro and in vivo. Advances in Enzyme Regulation 1999, 39:157-171.

23. Cain $K$, Langlais $C$, Sun XM, Brown DG, Cohen GM: Physiological concentrations of $\mathrm{K}^{+}$inhibit cytochrome c-dependent formation of the apoptosome. Journal of Biological Chemistry 2001, 276:41985-41990.
24. Yu SP, Yeh CH, Sensi SL, Gwag JB, Canzoniero LMT, Farhangrazi ZS, Ying HS, Tian M, Dugan LL, Choi DW: Mediation of neuronal apoptosis by enhancement of outward potassium current. Science 1997, 278:114-117.

25. Yu SP, Yeh C, Strasser U, Tian M, Choi DW: NMDA receptor-mediated $\mathrm{K}^{+}$ efflux and neuronal apoptosis. Science 1999, 284:336-339.

26. Krick S, Platoshyn O, Sweeney M, Kim H, Yuan JX: Activation of $\mathrm{K}^{+}$ channels induces apoptosis in vascular smooth muscle cells. American Journal of Physiology Cell Physiology 2001, 280:C970-C979.

27. Yu SP, Yeh CH, Gottron F, Wang X, Grabb MC, Choi DW: Role of the outward delayed rectifier $\mathrm{K}^{+}$current in ceramide-induced caspase activation and apoptosis in cultured cortical neurons. J Neurochem 1999. 73:933-941.

28. Jiang C, Agulian S, Haddad GG: $\mathrm{O} 2$ tension in adult and neonatal brain slices under several experimental conditions. Brain Res 1991, 568:159-164.

29. Friedman JE, Haddad GG: Anoxia induces an increase in intracellular sodium in rat central neurons in vitro. Brain Res 1994, 663:329-334.

30. Friedman JE, Haddad GG: Removal of extracellular sodium prevents anoxia-induced injury in freshly dissociated rat CA1 hippocampal neurons. Brain Res 1994, 641:57-64

31. Waxman SG, Black JA, Ransom BR, Stys PK: Anoxic injury of rat optic nerve: ultrastructural evidence for coupling between $\mathrm{Na}^{+}$influx and $\mathrm{Ca}(2$ $\left.{ }^{+}\right)$-mediated injury in myelinated CNS axons. Brain Res 1994, 644:197-204.

32. Gleitz J, Tosch C, Beile A, Peters T: The protective action of tetrodotoxin and (+/-)-kavain on anaerobic glycolysis, ATP content and intracellular $\mathrm{Na}^{2+}$ and $\mathrm{Ca}^{2+}$ of anoxic brain vesicles. Neuropharmacology 1996, 35:1743-1752.

33. Chidekel AS, Friedman JE, Haddad GG: Anoxia-induced neuronal injury: role of $\mathrm{Na}^{+}$entry and $\mathrm{Na}^{+}$-dependent transport. Exp Neurol 1997, 146:403-413.

34. Stys PK, Lopachin RM: Mechanisms of calcium and sodium fluxes in anoxic myelinated central nervous system axons. Neuroscience 1998 82:21-32.

35. Banasiak KJ, Burenkova O, Haddad GG: Activation of voltage-sensitive sodium channels during oxygen deprivation leads to apoptotic neuronal death. Neuroscience 2004, 126:31-44.

36. Galland L: Magnesium, stress and neuropsychiatric disorders. Magnes Trace Elem 1992, 10(Suppl 2-4):287-301.

37. Iotti S, Malucelli $\mathrm{E}$ : In vivo assessment of $\mathrm{Mg} 2+$ in human brain and skeletal muscle by 31P-MRS. Magnes Res 2008, 21(Suppl 3):157-62.

38. Faulker WR, Meites S: Selected methods for the small clinical chemistry laboratory Washington, DC; 1982

39. Henry RL, Cannon DC, Winklemen JW: Clinical Chemistry Principles and Techniques. 2 edition. Hagerstown, MD: Harper and Row; 1974.

40. Tietz NW: Fundamentals of Clinical Chemistry WB, Saunder Co, Philadelphia PA; 1982,874

41. Lindstrom $\mathrm{F}$, Diehl $\mathrm{H}$ : Indicator for the titration of calcium plus magnesium with (ethylenedinitrilo)tetraacetate. Anal Chem 1960, 32:1123.

42. Klein B, Oklander M: Clin Chem 1976, 13:26.

43. Rees $S$, Harding R, Walker D: The biological basis of injury and neuroprotection in the fetal and neonatal brain. Int J Devl Neuroscience.

44. Dalitz P, Harding R, Rees SM, Cock ML: Prolonged reductions in placen- tal blood flow and cerebral oxygen delivery in preterm fetals heep exposed to endotoxin: possible factors in white matter injury after acute infection. J Soc Gynecol Investig 2003, 10:283-290.

45. Duncan JR, Cock ML, Suzuki K, Scheerlinck JP, Harding R, Rees SM: Chronic endo toxin exposure causes brain injury in the ovine fetus in the absence of hypoxemia. J Soc Gynecol Investig 2006, 13:87-96.

46. Yan E, Castillo-Melendez M, Nicholls T, Hirst J, Walker D: Cerebrovascu- lar responses in the fetal sheep brain to low-dose endotoxin. Pediatr Res 2004, 55:855-863, 1531

47. Beutler B, Cerami A: The biology of cachectin/TNFa a primary mediator of host response. Annu Rev Immunol 1989, 7:625-655.

48. Singh VK: Phenotypic expression of autoimmune autistic disorder (AAD): A major subset of autism. Annals of Clinical Psychiatry 2009, 21(3):148-161.

49. Mundle SD, Reza S, Ali A, Mativi BY, Shetty V, Venugopal P, Gregory SA, Rasa A: Correlation of tumor necrosis factor a (TNFa) with high Caspase3-like activity in myelodysplastic syndromes. Cancer Letters 1999, 140:201-207.

50. Dimayuga FO, Wang C, Clark JM, Dimayuga ER, Dimayuga VM, Bruce AJ: SOD1 overexpression alters ROS production and reduces neurotoxic 
inflammatory signaling in microglial cells Keller. Journal of Neuroimmunology 2007, 182:89-99.

51. Al-Gadani Y, El-Ansary A, Attas O, Al-Ayadhi L: Oxidative stress and antioxidant status in Saudi autistic children. Clin Biochem 2009, 42:1032-1040

52. Shearer T, Larson IC, Neurochwonder J: Minerals in the Hair and Nutrient Intake of Autistic Children. Journal of Autism and Develop Disorders 1982, 12:25-34.

53. Krey JF, Dolmetsch RE: Molecular mechanisms of autism: a possible role for $\mathrm{Ca}^{2+}$ signalling. Opin Neurobiol 2007, 17:112-119.

54. Laura V, Cristina L, Paola R, Luisa AM, Shyti G, Edvige V, Giuseppe M, Elena G, Laura C, Adriana V: Metals, metallothioneins and oxidative stress in blood of autistic children. Research in Autism Spectrum Disorders 2011, 5:286-293.

55. Palmieri L, Persico AM: Mitochondrial dysfunction in autism spectrum disorders: cause or effect? Biochim Biophys Acta 2010, 1797(6-7):1130-1137.

56. El-Ansary A, Al-Daihan S, Al-Dbass A, Al-Ayadhi L: Measurement of selected ions related to oxidative stress and energy metabolism in Saudi autistic children. Clinical Biochemistry 2010, 43:63-70.

57. Palmieri L, Pardo B, Lasorsa FM, del Arco A, Kobayashi K, lijima M, Runswick MJ, Walker JE, Saheki T, Satrustegui J, Palmieri F: Citrin and aralar1 are $\mathrm{Ca}^{2+}$-stimulated aspartate/glutamate transporters in mitochondria. EMBO J 2001, 20:5060-5069.

58. Satrústegui J, Contreras L, Ramos M, Marmol P, del Arco A, Saheki T, Pardo B: Role of aralar, the mitochondrial transporter of aspartateglutamate, in brain $\mathrm{N}$-acetylaspartate formation and $\mathrm{Ca}^{2+}{ }^{2+}$ signaling in neuronal mitochondria. J Neurosci Res 2007, 85:3359-3366.

59. Xiao AY, Homma $M$, Wang $X Q$, Wang $X$, Yu SP: Role of $K(+)$ efflux in apoptosis induced by AMPA and kainate in mouse cortical neurons. Neuroscience 2001, 108(1):61-67.

60. Pigozzi D, Tombal B, Ducret T, Vacher P, Gailly P: Role of store-dependent influx of $\mathrm{Ca} 2+$ and efflux of $\mathrm{K}+$ in apoptosis of $\mathrm{CHO}$ cells. Cell Calcium 2004, 36(5):421-30.

61. Viviani B, Gardoni F, Marinovich M: Cytokines and neuronal ion channels in health and disease. Int Rev Neurobiol 2007, 82:247-63.

62. Leonoudakis D, Zhao P, Beattie EC: Rapid tumor necrosis factor alphainduced exocytosis of glutamate receptor 2-lacking AMPA receptors to extrasynaptic plasma membrane potentiates excitotoxicity. J Neurosci 2008, 28(9):2119-2130

doi:10.1186/1742-2094-8-142

Cite this article as: El-Ansary et al:: Proinflammatory and proapoptotic markers in relation to mono and di-cations in plasma of autistic patients from Saudi Arabia. Journal of Neuroinflammation 2011 8:142.

\section{Submit your next manuscript to BioMed Central and take full advantage of:}

- Convenient online submission

- Thorough peer review

- No space constraints or color figure charges

- Immediate publication on acceptance

- Inclusion in PubMed, CAS, Scopus and Google Scholar

- Research which is freely available for redistribution

Submit your manuscript at www.biomedcentral.com/submit
Biomed Central 